\title{
Diffuse axonal injury caused by assault
}

\author{
D I Graham, J C Clark, J H Adams, T A Gennarelli
}

\begin{abstract}
The case reports of $\mathbf{5 0}$ fatal head injuries caused by assault and managed at the Institute of Neurological Sciences, Glasgow, were reviewed. Fifteen cases had diffuse axonal injury.

Diffuse axonal injury is a well recognised type of brain damage brought about by a head injury, usually as a result of a road traffic accident or fall from a height. It does not seem to be widely appreciated that it may also occur as a result of an assault. This has important medicolegal implications.
\end{abstract}

Diffuse brain damage and diffuse axonal injury (DAI) are largely attributable to acceleration or deceleration of the type and magnitude associated with road traffic accidents and less frequently with falls from a height. ${ }^{1}$ This study is a review of the Department's experience of DAI resulting from an assault.

\section{Methods}

Full necropsies were performed on the 50 fatal head injuries due to assault in our database. All had been managed by the Department of Neurosurgery at the Institute of Neurological Sciences, Glasgow, between 1968 and 1990. In 15 of the 50 cases there was diffuse axonal injury. There were 13 men and two women with an age range between 17 and 83 years (average 38.3 years). Survival ranged from 26 hours to 21 months (average 87 days). The cause of injury was determined as far as possible from the medicolegal records (table). Eleven of the cases were in coma from the time of injury and four experienced a partial lucid interval ${ }^{2}$ they were able to talk in a a confused manner a short time after the injury. Comprehensive histological studies were carried out, as described previously. ${ }^{3}$

Department of Neuropathology D I Graham $\mathrm{J}$ H Adams

Department of Forensic Medicine and Science

J C Clark

Division of

Neurosurgery,

University of

Pennysylvania, USA

T A Gennarelli

Correspondence to: Professor D I Graham

Accepted for publication 20 January 1992 \footnotetext{
which they were minimal (TCI 1-10), three in which they were mild (TCI 11-20), one in which they were moderate (TCI 21-30) and

Results

Of the 15 cases in this study, DAI was grade 3 in 10 , grade 2 in one, and grade 1 in $4 .{ }^{4}$ In microscopic examination.

There was a fracture of the skull in five cases; it was depressed in three. The contusion index ranged from zero to 61 (average 9.9); there
}

one in which they were severe. Large intracranial haematomas (TCI of $>30$ ) were present in four cases, all of which were supratentorial: of these one was pure subdural, one pure extradural, one pure intracerebral and in one there was a "burst" temporal lobe.

Ischaemic damage was present in 11 of the cases: it was mild in seven, moderately severe in two, and severe in two. There were four cases in which there was no ischaemic damage.

There was swelling of the brain in four cases: in three it was unilateral and in one bilateral.

Evidence that the intracranial pressure had been high during life was found in seven cases. In one case acute bacterial meningitis was found.

\section{Discussion}

The finding of 15 cases with DAI as a result of an assault was rather surprising as previous studies have suggested that it was largely caused by injuries to the head of the type associated with either road traffic accidents or a fall from a height, ${ }^{13}$ and rarely after an assault. ${ }^{5}$ As in other cases of DAI a gradient of severity of injury was also found in the current series of cases following assault. ${ }^{4}$

Particular attention was paid to details surrounding the assault. Most of the cases in this study were involved in a brawl that resulted in an exchange of punches, which in some was also associated with additional blows to the head by kicking or heavy objects. In some instances, as a result of punching, the victim had an accelerated fall striking his head on the ground, kerb, or pavement. In some instances there was no punching, blows to the head being delivered by heavy objects made either of wood or metal. Unfortunately, precise details are not known and it is perhaps not surprising, therefore, that it has not been possible to identify a type of assault that predisposes to a particular pattern of damage and to identify a causal association between the mechanism of injury in those cases either with or without diffuse axonal injury.

Diffuse axonal injury has not been described in any of the review articles reporting the neurological sequelae of boxing. ${ }^{67}$ Acute neurological sequelae of boxing are largely due to the formation of either subdural or intracerebral haematomata. The best known chronic sequel of boxing is the development of dementia pugilistica the neuropathology of which includes changes in the septum pellucidum, scarring of the cerebellar tonsils, depigmentation of the substantia nigra, numerous 
Data on 15 patients with diffuse axonal injury

\begin{tabular}{|c|c|c|c|c|c|c|c|c|c|c|c|c|c|}
\hline Patient & Sex & Age & $\begin{array}{l}\text { Lucid } \\
\text { interval }\end{array}$ & Survival & $\begin{array}{l}\text { Cause } \\
\text { of } \\
\text { injury }\end{array}$ & $\begin{array}{l}\text { Fracture } \\
\text { of } \\
\text { skull }\end{array}$ & $\begin{array}{l}\text { Large } \\
\text { Intra- } \\
\text { cranial } \\
\text { haematoma }\end{array}$ & $\begin{array}{l}\text { Total } \\
\text { contusion } \\
\text { index }\end{array}$ & $\begin{array}{l}\text { Severity } \\
\text { of } \\
\text { ischaemic } \\
\text { brain } \\
\text { damage }\end{array}$ & $\begin{array}{l}\text { Diffuse } \\
\text { swelling }\end{array}$ & $\begin{array}{l}\text { Evidence } \\
\text { of high } \\
\text { intra- } \\
\text { cranial } \\
\text { pressure }\end{array}$ & $\begin{array}{l}\text { Grade } \\
\text { of } \\
D A I\end{array}$ & $\begin{array}{l}\text { Other } \\
\text { pathologies }\end{array}$ \\
\hline 1 & $\mathbf{M}$ & 47 & None & $2 \mathrm{~m}$ & Punch & - & - & 5 & - & - & - & 3 & - \\
\hline 2 & $\mathbf{M}$ & 18 & None & $21 \mathrm{~m}$ & Punch & - & - & 6 & Mild & - & + & 3 & - \\
\hline 3 & $\mathbf{M}$ & 59 & None & $2 \mathrm{~m}$ & Punch and fall & - & - & 2 & - & - & - & 3 & - \\
\hline 4 & $\mathbf{M}$ & 25 & None & $4 w$ & Punch and kicks & + & - & 13 & - & - & - & 3 & - \\
\hline 5 & $\mathbf{M}$ & 52 & None & $14 \mathrm{~d}$ & Punch & - & - & 0 & Moderate & - & - & 3 & - \\
\hline 6 & $\mathbf{M}$ & 83 & None & $6 d$ & $\begin{array}{l}\text { Blows from piece of } \\
\text { wood }\end{array}$ & + & - & 16 & Mild & - & - & 3 & - \\
\hline 7 & $\mathbf{F}$ & 18 & Partial & $26 \mathrm{~h}$ & $\begin{array}{l}\text { Blows from metal } \\
\text { crowbar }\end{array}$ & $\mathrm{D}+$ & R ICH & 25 & Mild & $\mathbf{R}$ & + & 1 & Acute meningitis \\
\hline 8 & $\mathbf{M}$ & 22 & None & $7 \mathrm{~d}$ & Punch and kick & - & - & 5 & Mild & - & - & 3 & - \\
\hline 9 & $\mathbf{M}$ & 17 & None & $6 \mathrm{~d}$ & $\begin{array}{l}\text { Sticks and blows } \\
\text { from bricks and } \\
\text { punch }\end{array}$ & $\mathrm{D}+$ & R SDH & 12 & Moderate & $\mathbf{R}$ & + & 3 & - \\
\hline 10 & $M$ & 62 & None & $5 \mathrm{~d}$ & Blows from hammer & $\mathrm{D}+$ & L ICH SDH & 61 & Mild & B & + & 2 & - \\
\hline 11 & M & 17 & Partial & $5 \mathrm{~m}$ & $\begin{array}{l}\text { Punch and blows } \\
\text { from basebal bat }\end{array}$ & - & L EDH & 3 & Mild & - & + & 1 & - \\
\hline 12 & $\mathrm{~F}$ & 52 & None & $11 \mathrm{~d}$ & $\begin{array}{l}\text { Punch and blows } \\
\text { from unknown ob- } \\
\text { ject }\end{array}$ & - & - & 0 & Mild & - & - & 3 & - \\
\hline 13 & $\mathbf{M}$ & 43 & None & $10 \mathrm{~m}$ & Punch and fall & - & - & 0 & - & - & + & 3 & - \\
\hline 14 & $\mathbf{M}$ & 29 & Partial & $12 \mathrm{~d}$ & $\begin{array}{l}\text { Punch and blows } \\
\text { from metal pipe }\end{array}$ & - & - & 0 & Severe & - & - & 1 & - \\
\hline 15 & $\mathbf{M}$ & 30 & Partial & $16 \mathrm{~d}$ & Punch and fall & - & - & 0 & Severe & $\mathbf{R}$ & + & 1 & - \\
\hline
\end{tabular}

$d=$ days; $\mathrm{w}=$ weeks; $\mathrm{m}=$ months; $\mathrm{h}=$ hours; $\mathrm{D}+=$ depressed fracture; $\mathbf{R}=$ Right; $\mathrm{L}=$ Left; $\mathrm{B}=$ Bilateral; $\mathrm{ICH}=\mathrm{Intracerebral}$ haematoma; EDH $=$ Extradural haematoma; SDH $=$ Subdural haematoma

For definitions of large intracranial haematoma, total contusion index, severity of ischaemic brain damage, evidence of high intracranial pressure and grade of DAI see Adams.

neurofibrillary tangles, ${ }^{6}$ and more recently with the multifocal deposition of $\beta$ protein as diffuse plaques. ${ }^{7}$

Although this study has established that all grades of DAI occur in fatal head injuries due to assault, the mechanism of its causation is unclear. The lack of full information surrounding the assault clearly leaves open the possibility that the victims sustained injuries other than those simply due to punching. Therefore, this study cannot determine whether DAI was produced by the assault itself, by the ensuing fall to the ground, or by a combination of the two. In any case the combination of head motions that resulted clearly exceeded the acceleration conditions that are necessary to produce diffuse axonal injury. ${ }^{8-10}$

This study was supported by project grants from the Medical Research Council and the Institute of Neurological Sciences Resesarch Trust. We are grateful to the forensic pathologists in the West of Scotland for having allowed us access to the case the West of Scotland for having allowed us access to the case material, to Mr L Miller, senior chief MLSO and his staff in the Whyte for having typed the manuscript.
1 Adams JH, Graham DI, Gennarelli TA, Maxwell WI Diffuse axonal injury in non-missile head injury. $¥$ Neurol Diffuse axonal injury in non-missile

2 Reilly PL, Graham DI, Adams JH, Jennett B. Patients with head injuries who talk and die. Lancet 1975;ii:375-7.

3 Adams JH. Brain damage in fatal non-missile head injury in man. In: Braakman R, ed. Head injury. Handbook of clinical neurology. Vol 13. Amsterdam: Elsevier Science Publishers BV, 1990:43-63.

4 Adams JH, Doyle D, Ford I, Gennarelli TA, Graham DI, McLellan DR. Diffuse axonal injury in head injury: definitions, diagnosis and grading. Histopathology 1989; 15:49-59.

5 Imajo T, Challener RC, Roessman U. Diffuse axonal injury by assault. Am ₹ For Med Pathol 1987;8:217-9.

6 Corsellis JAN, Bruton CJ, Freeman-Browne D. The aftermath of boxing. Psychol Med 1973;3:270-303.

7 Roberts GW, Allsop D, Bruton C. The aftermath of boxing. I Neurol Neurosurg Psychiatr 1990;53:373-8.

8 Pincemaille Y, Trosseille X, Mack P, Tarriere C, Breton F, Rennault B. Some new data related to human tolerance obtained from volunteer boxers. In: Proceedings of the 33rd Stapp Car Crash Conference. Warrindale, Pennsylvania: Society of Automotive Engineers, 1989:177-90.

9 Gennarelli TA, Thibault LE, Tomei G, Wiser R, Graham D, Adams J. Directional dependence of axonal brain injury due to centroidal and non-centroidal acceleration. In: Proceedings of the 31 st Stapp Car Crash Conference. New York: Society of Automotive Engineers, 1987: 35-53.

10 Margulies SS, Thibault LE, Gennarelli TA. Physical model simulations of brain injury in the primate. $\mathcal{F}$ Biomehanics 1989;23:823-36. 